\title{
Role of Primary Health Care teams in rapid testing for Sexually Transmitted Infections
}

\author{
Atuação das equipes de Atenção Primária à Saúde no teste rápido \\ para Infecções Sexualmente Transmissíveis
}

Túlio César Vieira de Araújo', Marize Barros de Souza'

DOI: $10.1590 / 0103-11042021131101$

\begin{abstract}
This research aims at describing the professional practices of Primary Health Care teams regarding rapid tests for STDs. It follows a descriptive study under a quantitative approach; participants include 18 municipalities, 94 Basic Health Units, and 100 staff teams working on Family Health Strategies. The sample was composed of the managers and the staff members directly involved in the testing, while the variables included adhesion to the tests and factors regarding the testing process. Data collection was performed in loco through a semi-structured instrument. Rapid tests were offered by $93 \%$ of the teams, $78.5 \%$ offering the tests to any users. In $89.2 \%$ of the staff teams, the nurse was solely responsible for collecting tests; $55.9 \%$ of members did not feel confident about reporting on a positive result, while $63.1 \%$ of those who considered the community health agent the main form of outreach assessed their performance as inadequate. Treatment against syphilis accounts for $50.5 \%$. There is fair adhesion to testing by part of the staff teams; the focus on the nurse, however, leads to an increase in their workload, highlighting their protagonism, leading to a reflection on professional practices and paving the way for different realities to be further investigated
\end{abstract}

KEYWORDS Primary Health Care. Sexually Transmitted Diseases. HIV. Syphilis. Professional practice.

RESUMO A pesquisa objetivou descrever a prática profissional das equipes de Atenção Primária à Saúde quanto ao teste rápido para as Infecções Sexualmente Transmissíveis. Estudo descritivo com abordagem quantitativa. Participaram 18 municípios, 94 Unidades Básicas de Saúde e 100 equipes de Estratégia Saúde da Família, a amostra foi composta pelo gestor das unidades e pelo profissional diretamente envolvido na testagem, as variáveis envolveram a adesão aos testes e os fatores relacionados com o processo de testagem, a coleta de dados ocorreu in loco com instrumento semiestruturado. O teste rápido é oferecido por $93 \%$ das equipes, 78,5\% o oferecem a quaisquer usuários. Em 89,2\% das equipes, somente o enfermeiro coletava o teste, $55,9 \%$ não se sentem seguros de informar um resultado positivo, 63,1\% dos que classificaram o agente comunitário de saúde como principal forma de divulgação julgaram essa atuação como inadequada. $O$ tratamento para sífilis é realizado por 50,5\%. Há uma boa adesão ao teste por parte das equipes, contudo, a centralidade da atividade no enfermeiro leva a uma sobrecarga de trabalho ao mesmo tempo que revela o protagonismo da categoria, o que proporciona uma reflexão sobre a prática profissional e abre espaço para que diferentes realidades sejam investigadas.

1 Universidade Federal profissional.

PALAVRAS-CHAVE Atenção Primária à Saúde. Infecções Sexualmente Transmissíveis. HIV. Sífilis. Prática 


\section{Introduction}

Sexually Transmitted Infections (STIs) are problems of individual and collective spheres; these include hepatitis B and C, syphilis and HIV. The World Health Organization (WHO) estimates that, annually, there are about 1.34 million deaths associated with viral hepatitis and that, among them, $96 \%$ are associated with hepatitis B or C; the number of deaths is comparable to deaths due to tuberculosis and higher than those related to HIV'.

About HIV, in 2019, 41,919 cases were reported in Brazil, with the Northeast being the second region with more notifications $(25.6 \%)$. Added to this is the fact that, in 2019, of the 10,565 deaths with HIV/Aids as the underlying cause, the Northeast was the second region with the highest number of deaths, representing $23 \%$ of the total. The standardized mortality coefficient for the period 2009 to 2019 showed a reduction of $29.3 \%$ in the country; however, in the same period, six Brazilian states showed an increase in their coefficients, including Rio Grande do Norte (RN) ${ }^{2}$.

In 2016, syphilis was declared a serious public health problem in Brazil. From 2017 to 2019 , the detection rate of acquired syphilis increased from 59 to 72.8 cases per 100,000 inhabitants. Of the 61,127 cases of gestational syphilis reported in 2019, the Northeast region stands out with 13,026 cases (21.3\%), only behind the Southeast region. There was a reduction of $8.7 \%$ in the number of reports of congenital syphilis in the country from 2018 to 2019; however, ten states had incidence rates higher than the national rate, in which the RN is the fifth state with the highest number of cases, with a rate of 12.3 cases in every 1,000 live births ${ }^{3}$, showing the existence of obstacles in the diagnosis and treatment of gestational syphilis.

For most infectious diseases, a quick and accurate diagnosis is a crucial public health strategy, with the objective of implementing an earlier and more effective treatment, consequently interrupting the chain of transmission sustained by untreated cases ${ }^{4}$. Based on technological evolution, new policies have been adopted with the objective of expanding the diagnosis; among the proposed innovations is the diagnosis through Rapid Tests (RT). RTs are chromatographic immunoassays of simple execution, with results in up to 30 minutes, carried out in a non-laboratory environment with a sample of whole blood obtained by digital or venous puncture and Oral Fluid (OF) ${ }^{\mathbf{5}, \mathbf{6}}$.

Despite the relevance of the RT, its implementation in Brazilian Primary Health Care (PHC), which took place in 2012 through Ordinance No. 77 , faces barriers related to infrastructure, logistics, training of professionals and lack of knowledge of the population ${ }^{7}$. The decentralization and implementation of RT in PHC is a complex and multifaceted phenomenon, involving not only the worker's personal will, but also the structural conditions for the process to be developed, as well as awareness, monitoring and qualification mechanisms, assigning it a sense of co-responsibility and sharing rather than a simple transfer of responsibility ${ }^{8}$.

Promoting the decentralization IST's RT at PHC is an important and necessary step, however, it is not enough to provide the population with access to the service, it is indispensable that the testing takes place with the required quality conditions, both for users and professionals. In this decentralization process, it is essential to identify the main challenges and outline alternatives to overcome them in the best possible way', which reinforces the importance of investigating and elucidating the issue that, in addition to presenting a social dimension, is intertwined with health politics, planning and management.

Considering the knowledge gaps, as this is a recent issue in $\mathrm{PHC}$, associated with the mortality rate caused by hepatitis B and $\mathrm{C}$, the syphilis epidemic and the relevance of HIV in the global, national and regional 
context, it is justified the importance of this study that aims to: describe the professional practice of $\mathrm{PHC}$ teams with regard to RT for STIs.

\section{Material and methods}

Exploratory, descriptive study with a quantitative approach. The research setting was the historically constructed region of Seridó, $\mathrm{RN}$, Brazil, a region that encompasses the 23 municipalities that, directly or indirectly, emerged from the municipality of Caicó ${ }^{10}$. The region was chosen because of the history of low adherence of teams to the RT, according to the results of the National Program for Improving Access and Quality of Primary Care (PMAQ-AB), the absence of studies on the subject in that place and because it is in the region where the researcher works.

The state of RN is currently divided into eight health regions, according to Deliberation No. 909/13-CIB/RN. The 23 municipalities in this study are part of the 4th Health Region. Of the 23 municipalities that make up the scenario of this study, 18 managers delivered the consent letter, thus, the 18 participating cities total 100 Basic Health Units (UBS) and 110 teams of Family Health Strategy (ESF).

In the UBS, the following inclusion criteria were used: being in operation during the period of data collection and being a member of the ESF, operating for more than six months. Regarding the care professional: having higher education and being linked to the UBS. One UBS was excluded because it was the workplace of one of the researchers responsible for this study.

An intentional sample was carried out with two professionals, the professional responsible for managing the unit and a care professional who was directly involved in the testing. In services where there was no manager and in teams that did not perform RT, professionals who had a broad knowledge of the information in the team's work process were interviewed. A pilot test was carried out with three ESF teams in a city bordering the setting of this study.

For data collection, a semi-structured instrument was used, which was divided into two domains, the first being a characterization of the health unit and the manager, based on questions from the external evaluation of the 3rd cycle of the PMAQ-AB. The second domain addressed variables related to the RT in the health team and was built during the literature review, with the main topics on the subject.

The full data were used for a research linked to a master's thesis. For the purposes of this study, the following variables were selected: UBS area; number of teams at UBS; unit management; team composition; characterization of the testing process; training of teams for the TR; ways of publicizing the test; testing in key populations; importance of testing in PHC; security in delivering the result; performing active search; flow of tested users; administration of benzathine penicillin in PHC; and test reliability.

Data were collected through on-site interviews, between July and November 2018, in a place that respected the interviewee's privacy and ensured the confidentiality of information. For a better understanding of the collected information, Microsoft Excel ${ }^{\circledR}$ 2010 was used to tabulate the data, in which the variables were grouped in columns, and the interviews, in lines. Then, to perform the statistical analyses, the information was analyzed with the Statistical Package for Social Sciences ${ }^{\circledR}$ (SPSS), version 20.0. In addition to the analyses, the application allowed the visualization of data in the form of graphs, tables and charts.

This research is in accordance with Resolution No. $466 / 12$ of the National Health Council and was approved by the Research Ethics Committee of the Federal University of Rio Grande do Norte, with Opinion 2,529,502 of 2018 . 


\section{Results}

Most of the UBS and participating teams were located in the urban area. In $72.3 \%$ of the teams, the professional nurse was divided between the care functions of the profession and the managerial functions of the basic health unit, $14 \%$ of the teams were not complete. Figure 1 discriminates the characteristics of the health teams and units participating in the study.

Figure 1. Characterization of the health units and teams participating in the study - Seridó Norte-rio-grandense. Natal, RN, Brazil, 2018

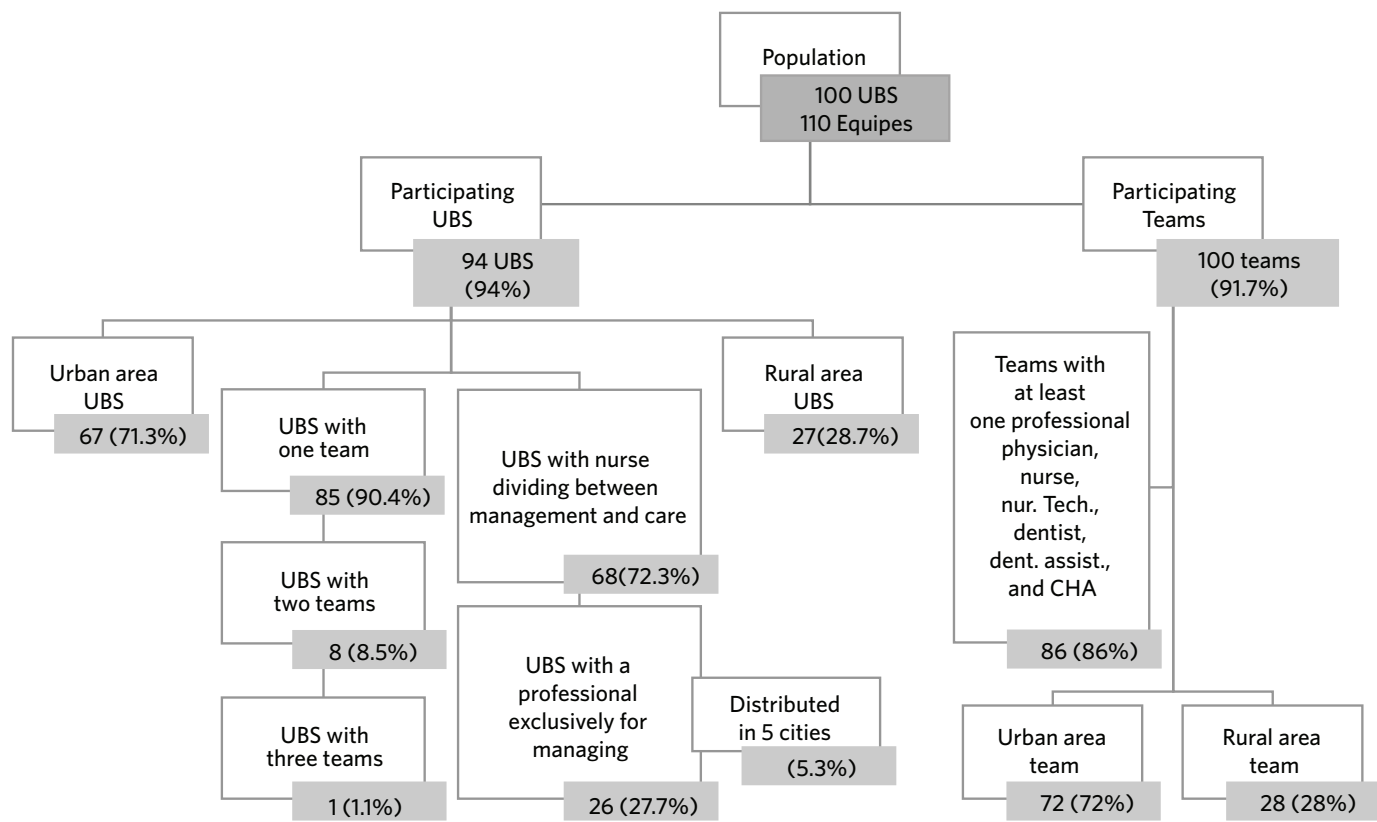

Source: Self elaborated.

The second domain of the instrument was designed to be answered by the healthcare professional who was directly involved in the testing. However, in the first interviews carried out in one of the municipalities, it was observed that this activity had the professional nurse as the protagonist, since, when answered by other professionals, the answers were insufficient for the purpose of this study, the nurse being established as the professional to be interviewed. The 18 municipalities included in the study had teams interviewed.

A total of 93 teams (93\%) offered RT for STI in the service routine. The seven teams (7\%) that did not offer were distributed in three cities, being three rural and four urban teams. The reasons mentioned were: absence of the test (three teams); inadequate UBS structure (two teams); lack of training (one team); change of physical structure (one team). The seven teams were complete with regard to professionals, five said they did not know about distance training for RT.

About the RT collection, in 83 teams (89.2\%), only the nurse performed the procedure; in seven teams (7.5\%), only the nursing technician; in one (1.1\%), both nurse and nursing technician collected; in one 
(1.1\%), the nurse, the nursing technician and the dentist; and one more team (1.1\%) reported that the pharmacist, social worker and nutritionist performed the collection for the test. In pre-test counseling and post-test counseling, the nurse is shown as the main involved, the medical professional is mentioned only in the post-test stage by one team. The characteristics of the pre- and post-test steps are shown in figure 2 .

Figure 2. Characteristics of the testing process and professionals involved in the Family Health Strategy teams - Seridó Norte-rio-grandense. Natal, RN, Brazil, 2018



Regarding the 93 teams that offered testing, 89 (95.7\%) offered the 4 tests; and 4 (4.3\%), only a few. Regarding access, 73 nurses (78.5\%) said that all users had access to the test; 14 (15\%), that access was restricted to the population of the area; 6 (6.5\%), that the test was only for pregnant women. With regard to frequency, 13 teams (14\%) offered the test daily; 43 (46.2\%), weekly; 21 (22.6\%), every two weeks; 13 (14\%) once a month; 37 responded that, in addition to the previous frequency, they also offered tests in campaigns; and 3 teams $(3.2 \%)$, only in campaigns.

In 78 teams (83.9\%), the professionals involved in the testing were trained; of the
15 teams (16.1\%) without training, 5 professionals (33.3\%) said they knew about distance training for RT, 10 (66.7\%) did not. The reasons given about why the professionals have not participated in the training were: "No training was offered" and "I was not invited". Of the trained teams, the nurse is appointed in all interviews as a trained professional for testing; the nursing technician was mentioned in 23 (29.4\%); the dentist, in 9 (11.5\%); the dental assistant, in 4 (5.1\%); and the doctor, in 2 interviews (2.5\%). The characteristics of the trained teams are shown in figure 3. 
Figure 3. Characteristics of the Family Health Strategy teams in which the professionals involved in the testing had been trained - Seridó Norte-rio-grandense. Natal, RN, Brazil, 2018

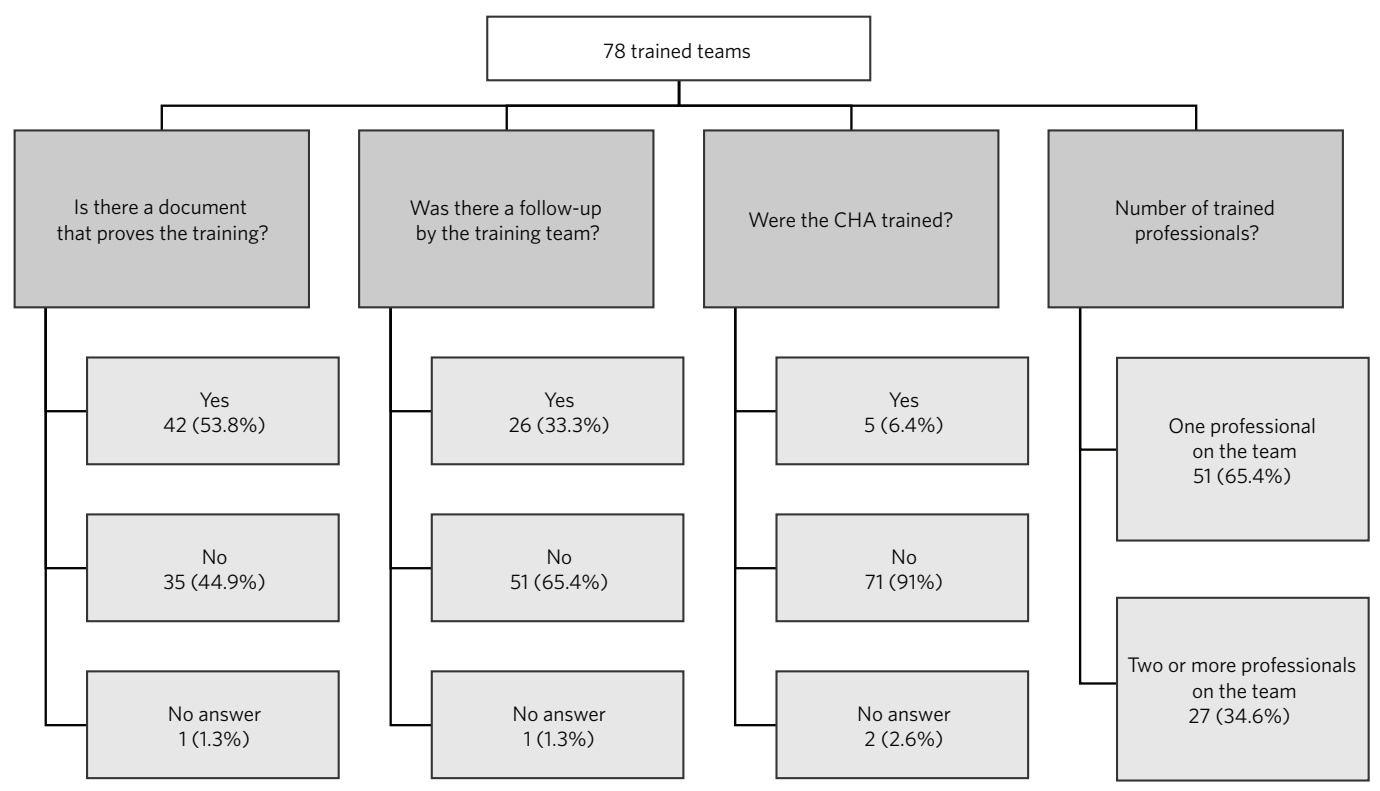

Source: Self elaborated.

The main form of dissemination of the tests mentioned by 65 respondents $(69.9 \%)$ was the Community Health Agent (CHA); followed by collective activity, 12 (12.9\%); and waiting room, 7 (7.5\%); 9 respondents (9.7\%) indicated "Another form of promotion". Promotion was considered inadequate by 60 professionals (64.5\%). If we consider the means of promotionto be the CHA, of the 65 interviews, 41 (63.1\%) said that the disclosure was not adequate.

When asked whether the population that attended the test presented risk behaviors, 28 (30.1\%) indicated that "The majority”, 64 (68.8\%) said "The minority", 1 interview (1.1\%) had no response. Regarding the importance of RT within the context of $\mathrm{AB}, 1$ nurse (1.1\%) judged it as not important. On the degree of importance on a scale from zero to 10, where zero meant unimportant and 10 meant maximum importance, the average was 9.59 , median 10 , mode 10 , minimum value 5 and maximum 10. Regarding the professional's degree of motivation to perform the RT, still on a scale from zero to 10 , the average was 8.2 , median 8 , mode 8 , minimum value 3 and maximum 10. Other factors related to the testing process are described in table 1. 
Table 1. Factors involved with the testing process in the teams of the Family Health Strategy - Seridó Norte-rio-grandense. Natal, RN, Brazil, 2018. ( $n=93$ )

\begin{tabular}{|c|c|c|c|c|c|c|}
\hline \multirow[b]{2}{*}{ Variable } & \multicolumn{2}{|c|}{ Yes } & \multicolumn{2}{|c|}{ No } & \multicolumn{2}{|c|}{ No answer } \\
\hline & n & $\%$ & n & $\%$ & n & $\%$ \\
\hline Is the result given on the same day as the collection? & 93 & 100 & 0 & 0 & 0 & 0 \\
\hline Does the responsible feel confident to report a positive result? & 41 & 44.1 & 52 & 55.9 & 0 & 0 \\
\hline Is the active search performed for positive cases that do not return? & 87 & 93.5 & 2 & 2.2 & 4 & 4.3 \\
\hline Is an active search for sexual partners carried out? & 78 & 83.9 & 12 & 12.9 & 3 & 3.2 \\
\hline $\begin{array}{l}\text { Is there a documented local/regional flowchart to be followed accord- } \\
\text { ing to the test result? }\end{array}$ & 12 & 12.9 & 81 & 87.1 & 0 & 0 \\
\hline $\begin{array}{l}\text { Does the referral/counter-referral flow in the specialty of sexually } \\
\text { transmitted infections work? }\end{array}$ & 27 & 29 & 61 & 65.6 & 5 & 5.4 \\
\hline Does the team have penicillin always available? & 81 & 87.1 & 12 & 12.9 & 0 & 0 \\
\hline Does the team apply penicillin in the basic unit? & 47 & 50.5 & 46 & 49.5 & 0 & 0 \\
\hline $\begin{array}{l}\text { Is the treatment of the pregnant woman's partner with syphilis indi- } \\
\text { cated without requesting an exam? }\end{array}$ & 11 & 11.8 & 81 & 87.1 & 1 & 1.1 \\
\hline Are the tests generally reliable? & 88 & 94.6 & 5 & 5.4 & 0 & 0 \\
\hline Is the rapid test using blood reliable? & 89 & 95.7 & 4 & 4.3 & 0 & 0 \\
\hline Is the rapid test using oral fluid reliable? & 62 & 66.7 & 28 & 30.1 & 3 & 3.2 \\
\hline
\end{tabular}

Source: Self elaborated.

\section{Discussion}

The UBS included in this study are characterized as predominantly urban and with a team. The survey showed satisfactory adherence, approximately $95 \%$ of the units and $92 \%$ of the teams participated in the study; however, the existing geographic distance between the units, the fact that only one professional is responsible for data collection and the interviewer's work routine acted as limiting factors in the presence of $100 \%$ of the planned demand.

The vast majority of the participating UBS (72.3\%) presented the nurse accumulating the care and management function of the unit. One of the characteristics of the daily life of the ESF is the work overload, caused by the accumulation of functions and the distancing of the nurse from direct care, which result from the need to provide answers to the demands related to the functioning of health services, to the population and, also, to established goals, agreements and service indicators. The prioritization of demands that require more urgent responses related to management leave nurses far from direct care, from the reality and health needs of the population"1.

With the first interviews, it was found that the nurse was the most appropriate professional to respond to the survey, as he mastered all the information inherent to testing. A study pointed out that the professionals who most participated in training to carry out counseling and RT for STIs in PHC in Brazil were nurses and, in some cases, physicians ${ }^{\mathbf{1 2}}$. Corroborating this finding, research showed that, among 24 primary care professionals trained to perform the RT, 20 were nurses, and only 4 were physicians ${ }^{\mathbf{1 3}}$.

The findings of this study converge with the two previous studies. Even though the results showed that most of the teams had been trained for testing, the details surrounding the training are noteworthy. In all trained teams, the nurse appears as a qualified professional, in $65.4 \%$ of the teams, only he was trained; however, the 
dentist was mentioned in nine interviews and the physician in two. The data support the choice of the nurse as the professional to be interviewed and confirm the finding that it was the nurses who were primarily responsible for the RT in the Brazilian PHC.

The need for more professionals to become skilled in the subject and also feel responsible for the process is emphasized. By sharing the responsibility, the overload in a given category is avoided and it contributes to an interdisciplinary and multidisciplinary health production. However, one of the country's health problems is the number of physicians in PHC is still below average, especially in riverside territories with difficult access ${ }^{\mathbf{1 4}}$, so the it may be impracticable due to the absence of the professional and the work overload, when present.

Even though the CHA is the most cited means of promotion, this promotion was analyzed by the majority as inadequate. It is pertinent to mention that, of the trained teams, in more than $90 \%$, the CHA did not participate in the training, which can accentuate this difficulty; however, the interviewees mentioned other factors, such as: apprehensiveness of the CHA in approaching the subject; stigma; work field extension; lack of motivation; absence of people during visiting hours; shortage of professionals; work overload; and inadequate work process. The data open a premise for a deeper investigation into the subject, even approaching other points of view, such as those of the CHA themselves.

The training certificate was only received by $53.8 \%$ of the interviewees, and $65.4 \%$ indicated the training as something punctual. A survey conducted in Santa Catarina, which interviewed professionals trained to perform the RT, showed that, upon completing the training, $80.6 \%$ said they answered all their doubts on the subject, but only $51.6 \%$ felt safe to carry out the diagnosis ${ }^{15}$.

Since the training may not be enough for the safety of those involved, the follow-up and continuity of training actions could support the professionals' anxieties. Even though there is no evidence in this research about this, certainly, numerous factors act as obstacles for the training team; however, what can be concluded is the existence of a weakness in training and that some points deserve to be revised in order to improve the work.

The work overload of nurses is evidenced when it is verified that, even the professional considering the RT an important tool in the context of PHC (degree of importance median and mode equal to 10), the degree of motivation presented a considerably lower value (degree of motivation - median and mode equal to 8). When asked about the reason for the lack of motivation, of the 61 who responded, work overload emerges in $34.4 \%$ of the reports.

Regarding the three moments that involve testing (pre-test counseling, test collection and post-test counseling), the nurse appears in approximately $90 \%$ of the teams as the only professional involved in all stages. Counseling is important, especially in the context of the RT. A systematic review pointed out counseling as a positive strategy, proving that the bond and the type of relationship established between the user and the counseling professional and its articulation with prevention practices influence behavior changes and treatment adherence ${ }^{\mathbf{1 6}}$.

The accumulation of all RT steps in a single category can contribute to a mechanical work, where speed becomes more important than service quality. In this sense, attention is drawn to the risk of technicization of the diagnosis, conceived as a process in which the emphasis of action falls on the offer and performance of the test itself, disconnected from the preventive approach, risk assessment and emotional support that characterize counseling ${ }^{\mathbf{8}}$. Counseling can promote awareness of prevention, adherence to treatment and reduction of the 
impact of the diagnosis, also expressing an ethical and political dimension, related to listening to the user and commitment to the joint construction of possibilities for solving problems ${ }^{\mathbf{8}, 17}$.

The most cited reason for not performing the test was the absence of the test, however, the limited number of teams that did not adhere to the procedure acts as a limiting factor in understanding the reason why the teams did not perform the RT. This research opens up possibilities for new questions, understanding that there are other factors associated with the resistance of professionals in the adherence to the $\mathrm{RT}$ as a routine in the work process. It is believed that the fact that some teams in this study offer only some of the RT is more associated with an absence of the input than with a personal resistance to that test.

The considerable advance in the adhesion of the teams to the RT is noteworthy, since, in the first cycle of the PMAQ 2011/2013, of the 26 participating Seridó teams, all marked the option "never available" for the RT for syphilis and HIV ${ }^{18}$. In the second cycle 2013/2014, of the 72 teams included, $36.1 \%$ stated that testing for syphilis was never available, and $31.9 \%$ stated that they did not perform RT for HIV ${ }^{19}$. In this research, the rate of absence of testing was $7 \%$, proving the effectiveness of the test decentralization process to the $\mathrm{PHC}$ and the increase in the adhesion of teams over time.

The high number of teams that provided the four tests favors access and provides users with a broader knowledge of their health status with regard to these infections. The efficiency of the work process is verified when it is observed that all teams provided the result on the same day. In line with this finding, a study carried out in Mexico found that the tests were performed in subsystems that were connected and with a certain dependence; the results were delivered the next day in the psychology sector, the process lasted for five to seven days ${ }^{20}$.
Testing was evidenced as an easily accessible mechanism for any user, regardless of residing in the UBS area. A minority of teams offered the test only to pregnant women. Regarding the frequency, most teams offered weekly, however, a constant in the professionals' report was the low demand for the service. The fact becomes more delicate when asked about the profile of users who attended to take the test, in which more than two-thirds said that the minority had risk behaviors.

The counter-reference of specialties in the area of STI did not exist for about two thirds of the interviewees. The conduct to be taken according to the test result could be based on a local/regional flowchart; however, in most teams (87.1\%) this document did not exist. A report on the implementation of RT in $\mathrm{PHC}$ found that the process was slowed down as the main finding, since, of the 31 health services, only two implemented RT during the study period. One of the main obstacles was the difficulty in developing an adequate workflow, $38.7 \%$ cited as justification the fact that they were unable to understand/develop a workflow, which brought insecurity in the patient's continuity with a reagent test ${ }^{15}$. The lack of guidelines on the flow to be followed feeds the professional's insecurity regarding the decisions to be taken according to the test result.

Still on insecurity, an aspect observed in a study developed at the UBS in Recife/ Pernambuco refers to the difficulties reported by respondents in post-test counseling, especially when the result was positive. The impact of this diagnosis is usually intense, both for the person and for the professional. Therefore, it is essential that the professional is prepared to offer emotional support, respecting the patient's time, as well as the reaction to the result. It was observed that the interviewed professionals still did not feel secure in performing the RT, nor in the post-test counseling with positive results ${ }^{21}$. 
The results of this study confirm the finding, since more than half of the interviewees said they were not confident to deal with a positive result. From this perspective, the existence of officially registered information, such as protocols or flowcharts, can act as a foundation for the professional's safety, who, no matter how emotionally insecure they are, would be technically supported.

RT that uses blood was considered by the majority (95.7\%) as a reliable technology, but when asked about the reliability of tests using OF, the trust was significantly reduced. Tests that use OF currently made available by the Ministry of Health are for the diagnosis of HIV. The OF contains fewer antibodies than whole blood, serum or plasma samples, but in sufficient quantity for a safe diagnosis, thus, the advantages of using this test outweigh its sensitivity limitation. Collecting the OF simplifies testing, as it is non-invasive, reduces biological risk and, above all, expands access to the diagnosis of HIV infection ${ }^{22-25}$.

Corroborating the information regarding the existing weaknesses in the insertion of RT in PHC, only $11 \%$ would initiate the presumptive treatment of the partner of the pregnant woman with syphilis without the confirmatory tests, going in opposition to what is recommended ${ }^{\mathbf{2 6}, \mathbf{2 7}}$. Attenuating the difficulty in controlling syphilis, it was found that approximately half of the teams did not administer benzathine penicillin at the UBS, even the majority (87.1\%) claiming to have it available.

According to the Federal Council of Nursing (Cofen), the great challenge for the administration of benzathine penicillin in UBS is the professionals' fear of adverse events happening ${ }^{2}$, especially the anaphylactic reaction, without having resources to reverse these conditions ${ }^{\mathbf{2 8}}$. However, research indicates that the occurrence of allergic reactions is estimated at $2 \%$, and anaphylactic reactions occur in only $0.01 \%$ to $0.05 \%$ of patients treated with penicil$\operatorname{lin}^{29,30}$. Such statistical data can be used as an incentive to administer penicillin in PHC.

This study has as a limitation the fact that it reflects a regional reality, which may not be the reality of the rest of the country, in view of the wide territorial extension and different regional contexts in Brazil. As contributions, the pioneering spirit in researching a scenario never studied in publications previously published on the subject stands out; thus, in daily practice, the research offers suggestions for the future of the services studied. As it is a topic of epidemiological and current relevance in the global debate, the study contributes to other research that may take place in different scenarios.

\section{Conclusions}

The decentralization of testing took place for the PHC teams in Seridó, with many points working satisfactorily. Even so, when analyzing the peculiarities that exist in the testing process, there are a series of weaknesses that show a superficial work, without the necessary foundation for the specificities that the $\mathrm{RT}$ requires.

Testing in the FHS was primarily absorbed by the nurse, a positive point when it is understood that the PHC contributes to the autonomy of the nurse, through the incorporation of new skills and technologies. However, in this studied reality, in most cases, the nurse was also responsible for the management of services. Thus, it becomes complex to see a technology that came to help the production of health, without conceptualizing it as another attribution, since the participation of other professionals was scarce. In a service in which nurses are routinely overloaded, adhering to a new demand with excellence in execution was a reality for few.

In this scenario, recommending that the RT become a multidisciplinary and 
interdisciplinary process is a delicate matter, but it is necessary, since the results and the literature point to the lack of certain professionals. However, it is worth reflecting on how the valuation and recognition of those who are mostly responsible for the service is going.

It is concluded that the RT is a viable, beneficial initiative, which can add to the reality of PHC. However, sometimes, it is necessary to go back to the base of the work process and reflect on how this care has been happening, since identifying the weaknesses and tracing the means for their solution is an important step in the adequacy of health services.

\section{Collaborators}

Araújo TCV (0000-0003-3991-0215)* and Souza MB (0000-0002-7539-9226)* equally contributed to the preparation of the manuscript.

\section{References}

1. World Health Organization. Global Hepatit is Report 2017. Geneva: WHO; 2017. [acesso em $2021 \mathrm{fev}$ 5]. Disponível em: https://www.who.int/hepatitis/ publications/global-hepatitis-report2017/en/.

2. Brasil. Ministério da Saúde, Secretaria de Vigilância em Saúde. Boletim epidemiológico HIV/Aids 2020. Brasília, DF: MS; 2020. [acesso em 2021 fev 5]. Disponível em: http://www.aids.gov.br/pt-br/pub/2020/ boletim-epidemiologico-hivaids-2020.

3. Brasil. Ministério da Saúde, Secretaria de Vigilância em Saúde, Departamento de Doenças de Condições Crônicas e Infecções Sexualmente Transmissíveis. Boletim epidemiológico sífilis 2020. Brasília, DF; 2020. [acesso em 2021 fev 5]. Disponível em: http://www. aids.gov.br/pt-br/pub/2020/boletim-sifilis-2020.

4. Hanafiah KM, Garcia M, Anderson D. Point-of-care testing and the control of infectious diseases. Bioma- rkers Med. 2013;7(3):333-347.

5. Brasil. Ministério da Saúde, Secretaria de Vigilância em Saúde. Manual Técnico para Diagnóstico da Sífilis. Brasília, DF: MS; 2016. [acesso em 2021 fev 5]. Disponível em: http://www.aids.gov.br/pt-br/pub/2016/ manual-tecnico-para-diagnostico-da-sifilis.

6. Brasil. Ministério da Saúde, Secretaria de Vigilância em Saúde. Manual técnico para o diagnóstico da infecção pelo HIV em adultos e crianças. Brasília, DF: MS; 2018. [acesso em 2021 fev 5]. Disponível em: http://www.aids.gov.br/pt-br/node/57787.

7. Mizevski VD, Brand EM, Calvo KS, et al. Disponibilidade do teste rápido para sífilis e anti-HIV nas unidades de atenção básica do Brasil, no ano de 2012. Saúde em Redes. 2017 [acesso em 2021 fev 8]; 3(1):40-49. Disponível em: http://revista.redeunida.org.br/ojs/ index.php/Rede-unida/article/view/823.
*Orcid (Open Researcher and Contributor ID). 
8. Zambenedetti G, Silva RAN. Descentralização da atenção em HIV-Aids para a atenção básica: tensões e potencialidades. Physis Rev. Saúde Colet. 2016; 26(3):785-806.

9. Araújo TCV, Souza MB. Adesão das equipes aos testes rápidos no pré-natal e administração da penicilina benzatina na atenção primária. Rev. esc. enferm. USP. 2020; (54):e03645.

10. Morais IRD. Seridó Norte-Rio-Grandense: uma geografia da resistência. Caicó: Ed. do autor; 2005.

11. Caçador BS, Brito MJM, Moreira DA, et al. Being a nurse in the family health strategy programme: challenges and possibilities. Rev Min Enferm. 2015; 19(3):612-626.

12. Rocha KB, Santos RRG, Conz J, et al. Network transversality: matrix support in the decentralization of counseling and rapid testing for HIV, syphilis, and hepatites. Saúde debate. 2016; 40(109):22-33.

13. Lopes ACMU, Araújo MAL, Vasconcelos LDPG, et al. Implementation of fast tests for syphilis and HIV in prenatal care in Fortaleza - Ceará. Rev Bras Enferm. 2016; 69(1):54-58.

14. Lima SVMA, Nunes J, Santos L, et al. O programa mais médicos e a atenção básica no Brasil: uma revisão integrativa. Gest. Soc. 2017; 11(30):1963-1975.

15. Nascimento DSF, Silva RC, Tártari DO, et al. Relato da dificuldade na implementação de teste rápido para detecção de sífilis em gestantes na Atenção Básica do SUS em um município do Sul do Brasil. Rev Bras Med Fam Comunidade. 2018; 13(40):1-8.

16. Soares PS, Brandão ER. O aconselhamento e a testagem anti-HIV como estratégia preventiva: uma revisão da literatura internacional, 1999-2011. Saúde Soc. 2012; 21(4):940-953.

17. Moreno DMFC. Aconselhamento para revelação do diagnóstico de infecção pelo HIV. In: Paiva V, Calazans G, Segurado A, organizadores. Vulnerabilidade e direitos humanos: Promoção e Prevenção da saúde. Curitiba: Juruá; 2013. p. 165-188. (Livro II).

18. Brasil. Ministério da Saúde, Secretaria de Atenção à Saúde. Brasília, DF: MS; 2011. [acesso 2021 fev 12]. Disponível em: https://aps.saude.gov.br/ape/pmaq/ ciclol/.

19. Brasil. Ministério da Saúde, Secretaria de Atenção à Saúde, Departamento de Atenção Básica. Microdados da avaliação externa. Brasília, DF: MS; 2013. [acesso em 2021 fev 12]. Disponível em: https://aps. saude.gov.br/ape/pmaq/ciclo2/.

20. Cuadra-Hernández SM, Bernabé-Aranda JI, Conde-Glez CJ, et al. Public health services and their relationship with rapid HIV test utilization and access for key populations in Morelos, Mexico. Salud Publica Mex. 2015 [acesso em 2021 fev 12]; 57(4):304-311. Disponível em: https://www.ncbi.nlm.nih.gov/pubmed/26395795.

21. Araújo WJ, Quirino EMB, Pinho CM, et al. Perception of nurses who perform rapid tests in Health Centers. Rev Bras Enferm. 2018; 71(supl1):676-681.

22. Guarner J. Human immunodeficiency virus: Diagnostic approach. Semin Diagn Pathol. 2017; 34(4):318324.

23. Cappello JM, Gunasekera A, Gunasekera D, et al. A multicenter performance evaluation of the DPP HIV-1/2 assay for the detection of HIV antibodies in various HIV testing algorithms. J Clin Virol. 2013; 58(supl1):59-64.

24. Granade TC, Phillips SK, Parekh B, et al. Detection of antibodies to human immunodeficiency virus type 1 in oral fluids: a large-scale evaluation of immunoassay performance. Clin Diagn Lab Immunol. 1998 [acesso em 2021 fev 15]; 5(2):171-175. Disponível em: https://www.ncbi.nlm.nih.gov/pubmed/9521138.

25. Pascom ARP, Barros CHD, Lobo TDM, et al. Point-of-care HIV tests done by peers, Brazil. Bull World Health Organ. 2016; 94(8):626-630. 
26. Brasil. Ministério da Saúde, Secretaria de Vigilância em Saúde. Protocolo clínico e diretrizes terapêuticas para prevenção da transmissão vertical de HIV, sífilis e hepatites virais. Brasília, DF: MS; 2018. [acesso em 2021 fev 15]. Disponível em: http://www.aids.gov. br/pt-br/pub/2015/protocolo-clinico-e-diretrizes-terapeuticas-para-prevencao-da-transmissao-vertical-de-hiv

27. Brasil. Ministério da Saúde, Secretaria de Vigilância em Saúde. Protocolo Clínico e Diretrizes Terapêuticas para Atenção Integral às Pessoas com Infecções Sexualmente Transmissíveis (IST). Brasília, DF: MS; 2018. [acesso em 2021 fev 15]. Disponível em: http:// www.aids.gov.br/pt-br/pub/2015/protocolo-clinico-e-diretrizes-terapeuticas-para-atencao-integral-pessoas-com-infeccoes.

28. Conselho Federal de Enfermagem. Nota técnica Cofen/CTLN No 03/2017. Brasília, DF: MS; 2017. [aces- so em 2021 fev 15]. Disponível em: http://www.cofen. gov.br/cofen-publica-nota-tecnica-sobre-administracao-da-penicilina-benzatina_52797.html.

29. Felix MMR, Kuschnir FC. Alergia à penicilina: aspectos atuais. Adolesc. Saúde. 2011 [acesso em 2021 fev 15]; 8(3):43-53. Disponível em: http://www.adolescenciaesaude.com/detalhe_artigo.asp?id=285\#.

30. Fundo das Nações Unidas para a Infância. Como prevenir a transmissão vertical do HIV e da Sífilis no seu Município. Brasília, DF: UNICEF; 2008. [acesso em 2021 fev 15]. Disponível em: http://bvsms.saude. gov.br/bvs/publicacoes/como_prevenir_transmissao_vertical_hiv_prof.pdf.

Received on 03/03/2021

Approved on 10/09/2021

Conflict of interests: non-existent

Financial support: non-existent 